JURNAL AL BAYAN: JURNAL JURUSAN PENDIDIKAN BAHASA ARAB

p-ISSN 2086-9282 | e-ISSN 2549-1229

\title{
Digital Material EPUB Based to Understand Tarkib: Is Flipped Classroom Effective?
}

\author{
Agus Riwanda ${ }^{1}$, Muhammad Ridha ${ }^{2}$, M. Irfan Islamy ${ }^{3}$ \\ ${ }^{1}$ Madrasah Aliyah Negeri 4 Hulu Sungai Tengah Kalimantan Selatan, Indonesia \\ ${ }^{2}$ Islamic Education Study Program Universitas Islam Negeri Antasari, Indonesia \\ ${ }^{3}$ Madrasah Ibtidaiyah Teacher Education Study Program Universitas Islam Negeri Antasari, Indonesia
}

\author{
Article History: \\ Received : October 31, 2020 \\ Revised : November 30, 2020 \\ Accepted : December 31, 2020 \\ Published : June 01, 2021
}

\section{Keywords:}

Arabic; Digital Book; Flipped

Classroom; Tarkib

*Correspondence Address: agusriwanda89@gmail.com

\begin{abstract}
Flipped Classroom strategy is blended learning that build students learning autonomy. However, student learning outcomes in X IPA 2 class of MAN 4 HST on tarkib material is still below the passing grade. Arabic is important to be mastered for better understanding in Islamic teaching from its sources. This study aimed to see and compared the students learning outcomes between the flipped classroom strategy with epub digital book teaching material and traditional strategy. Experimental research was used with a non equivalent control group design and intact group. The experimental class was X IPA 2 which consisted of 26 students and the control class was X IPA 1 which consisted of 29 students. The data were collecting from pretest, treatment, and posttest on the control and experimental class. The results of this study was found out which there was significant difference in the acquisition of learning outcomes. The experimental class which used digital book had better average learning outcomes than the control class which used conventional strategies. The significance value asymp. Sig (2-tailed) was 0.200 which was higher than 0.05 . So, there was a significant different from the results of the control and experimental class. This study also rejected that the flipped classroom strategy which was assisted with digital material which based on epub did not gain the significant result or better attitudes rather than the non-flipped classroom. This study contributed to enhancing the learning quality of Arabic in non-language class.
\end{abstract}

\section{Introduction}

Tarkib is an Arabic skill that needs to review sentences according to the grammatical rules of Arabic. Tarkib skill is essential skill for students ${ }^{1}$. Nunan confirmed that understanding of the language skills is determined the level of achievement ${ }^{2}$. Simultaneously, the result of other researches show that students in senior high school

${ }^{1}$ Aram Reza Sadeghi Beniss dan Vahid Edalati Bazzaz, "The Impact of Pushed Output on Accuracy and Fluency of Iranian EFL Learners' Speaking," Iranian Journal of Language Teaching Research 2, no. 2 (Juli 2014), https://doi.org/10.30466/ijltr.2014.20413. 
have difficulties in learning Arabic ${ }^{3,4,5}$. It might be caused by the use of traditional method which is not sufficient ${ }^{6,7}$. Thus, an exciting and innovative learning approach is needed to give more chances and experiences for the students.

Few researchers stated that the Flipped Classroom can enhance language skills effectively ${ }^{8,9,10}$. The Flipped Classroom can encourage students to engage more meaningful learning activities such as discussion, searching for learning resources, doing projects, and giving feedback, so, the students will be more independent and responsible for their learning ${ }^{11,12}$. Li and Suwanthep revealed that Flipped Classroom enables students to maximize their learning, and the teacher can encourage students to practice their foreign language skills by giving support and access to learning resources ${ }^{13}$. The Flipped Classroom offers an informal learning system and gives the opportunity to the teachers to provide meaningful and flexible activities for enhancing the students' language skills ${ }^{14}$.

2 David Nunan, Designing tasks for the communicative classroom (Cambridge: Cambridge University Press Cambridge, 2001), 2.

${ }^{3}$ Rozika Azizi, Anwar Sa'dullah, dan Mohammad Afifulloh, "Strategi Guru Mengatasi Kesulitan Belajar Siswa Pada Mata Pelajaran Bahasa Arab Di Madrasah Tsanawiyah Yaspuri Kota Malang," Vicratina: Jurnal Pendidikan Islam 4, no. 6 (13 Juli 2019): 102-12.

4 Zughrofiyatun Najah dan Azzah Saniyyah Maulana, "Mahârah Al-Kitâbah Learning Through Mind Mapping Strategies," Jurnal Al Bayan: Jurnal Jurusan Pendidikan Bahasa Arab 11, no. 2 (9 Desember 2019): 340-55, https://doi.org/10.24042/albayan.v11i2.5038.

${ }^{5}$ Muhammad Asep Saepul Islam, "Faktor Demotivasi Pembelajaran Bahasa Arab Dalam Perspektif Siswa Madrasah," Arabiyat: Jurnal Pendidikan Bahasa Arab dan Kebahasaaraban 2, no. 1 (2015): 1-16.

${ }^{6}$ Ibtehal Mahmoud Aburezeq, "The Impact of Flipped Classroom on Developing Arabic Speaking Skills," The Asia-Pacific Education Researcher 29, no. 4 (1 Agustus 2020): 295-306, https://doi.org/10.1007/s40299-019-00483-z.

7 Faturahman Fuadi, "Analisis Kesulitan Belajar Bahasa Arab:" Al-Lisan: Jurnal Bahasa (eJournal) 4, no. 2 (1 Agustus 2019): 161-69.

${ }^{8}$ Haifa Albahuoth, "Effectiveness of flipped classroom in developing 11th graders' grammatical competences in Arabic," Interactive Learning Environments, 2020, 1-17.

9 Jonathan Bergmann dan Aaron Sams, Flipped Your Classroom Reach Every Student Everyday Class Every Day, First Edit (Washington DC: International Society for Technology in Education, 2012), 4.

${ }^{10}$ Abdulrahman M Al-Zahrani, "From Passive to Active: The Impact of the Flipped Classroom through Social Learning Platforms on Higher Education Students' Creative Thinking," British Journal of Educational Technology 46, no. 6 (2015): 1133-48, https://doi.org/10.1111/bjet.12353.

11 Chiu-Lin Lai dan Gwo-Jen Hwang, "A Self-Regulated Flipped Classroom Approach to Improving Students' Learning Performance in a Mathematics Course," Computers \& Education 100 (1 September 2016): 126-40, https://doi.org/10.1016/j.compedu.2016.05.006.

12 Arina Evseeva dan Anton Solozhenko, "Use of Flipped Classroom Technology in Language Learning," Procedia - Social and Behavioral Sciences 206, no. November (2015): 205-9, https://doi.org/10.1016/j.sbspro.2015.10.006.

13 Shuangjiang Li dan Jitpanat Suwanthep, "Integration of flipped classroom model for EFL speaking," International Journal of Learning and Teaching 3, no. 2 (2017): 118-23.

${ }^{14}$ Jamie L Jensen, Tyler A Kummer, dan Patricia D M Godoy, "Improvements from a Flipped Classroom May Simply Be the Fruits of Active Learning," CBE-Life Science Education 14 (2015): 1-12, https://doi.org/10.1187/10.1187/cbe.14-08-0129. 
Previous researchers have revealed that the Flipped classroom is useful to enhance learning outcomes in the cognitive domain ${ }^{15}$. It can increase motivation of students in studying foreign languages, improve the comprehension of the material, and lead to meaningful learning activities ${ }^{16}$. The Flipped classroom is a kind of blended instructional model ${ }^{17}$ that offers instructional activities in mastering lower-order thinking skills ${ }^{18}$ such as the presentation basic concepts become explaining ideas and asking students to read, traditionally conducted in the classroom become home activities, learning outside become inside the classroom $^{19}$. In the implementation of flipped classroom, teachers deliver materials before the class ${ }^{20}$. The lower level students would be responsible understanding the contents, such as remembering, comprehending, and applying in thier daily life ${ }^{21}$. Teachers can assist students to be more engaged in their learning process such as analyzing, evaluating, and creating activities in the class ${ }^{22}$.

Researches show that Tarkib generally is the most difficult skill to be mastered ${ }^{23}$. Based on the experience of researchers, teaching tarkib in X IPA class also has the unique complexity compared to other classes. Students in IPA classes tend to have higher intelligence on logical-mathematical than verbal-linguistic. Also, the majority of students in IPA classes did not come from Islamic school, and also have never learnt Arabic

${ }^{15}$ Muhammad Ridha, Punaji Setyosari, dan Dedi Kuswandi, "Pengaruh Flipped Mastery Classroom Terhadap Perolehan Hasil Belajar Kognitif Mahasiswa," Jurnal Pendidikan: Teori, Penelitian, dan Pengembangan 1, no. 4 (2016): 655-61.

${ }^{16}$ Abdulrahman M. Al-Zahrani, "From Passive to Active: The Impact of the Flipped Classroom through Social Learning Platforms on Higher Education Students' Creative Thinking," British Journal of Educational Technology 46, no. 6 (2015): 1133-48, https://doi.org/10.1111/bjet.12353.

${ }^{17}$ Jonathan Bergmann dan Aaron Sams, Flip Your Classroom: Reach Every Student in Every Class Every Day (Washington, D.C, America: International Society for Technology in Education, 2012).

${ }^{18}$ Hamad Alsowat, "An EFL Flipped Classroom Teaching Model : Effects on English Language Higher-order Thinking Skills, Student Engagement and Satisfaction," Journal of Education And Practice 7, no. 9 (2016): 110.

${ }_{19}$ Babak Sohrabi dan Hamideh Iraj, "Implementing Flipped Classroom Using Digital Media: A Comparison of Two Demographically Different Groups Perceptions," Computers in Human Behavior 60 (1 Juli 2016): 514-24, https://doi.org/10.1016/j.chb.2016.02.056.

${ }^{20}$ Muhammad Ridha, Punaji Setyosari, dan Dedi Kuswandi, "Pengaruh Flipped Mastery Classrom Terhadap Perolehan Hasil Belajar Kognitif Mahasiswa," Jurnal Pendidikan: Teori, Penelitian, dan Pengembangan 1, no. 4 (1 April 2016): 655-61, https://doi.org/10.17977/jp.v1i4.6211.

${ }^{21}$ Jeong-eun Kim dan Hyunjin Park, "Exploring Flipped Classroom Effects on Second Language Learners' Cognitive Processing," Foreign Language Annals 50, no. 2 (2017): 279, https://doi.org/10.1111/flan.12260; Lucy Santos Green, Jennifer R Banas, dan Ross A Perkins, ed., The Flipped College Classroom: Conceptualized and Re-Conceptualized (Cham: Springer International Publishing Switzerland, 2017), 3.

${ }^{22}$ Hamad Alsowat, "An EFL Flipped Classroom Teaching Model: Effects on English Language Higher-Order Thinking Skills, Student Engagement and Satisfaction," Journal of Education and Practice 7, no. 9 (2016): 108-21.

${ }^{23}$ Aziz Fahrurrozi, "Pembelajaran Bahasa Arab: Problematika dan Solusinya," Arabiyat: Jurnal Pendidikan Bahasa Arab dan Kebahasaaraban 1, no. 2 (2014): 164.

3 | Jurnal Al Bayan: Jurnal Jurusan Pendidikan Bahasa Arab, 13 (1): 1-15 (2021) 
before. Besides, some students come from Madrasah Tsanawiyah (Islamic Middle School), tend to dislike Arabic. Thus, the lesson plans also is hard to implement. The teacher needs to retell the material for several times so that the learning process runs slowly. Unfortunatelly, the results of student learning outcomes are low. The average score of the tarkib learning outcomes of class X IPA students is 63 , it is below the minimum criteria score, which is 75 .

Nowadays, some evidences show that students have been more reliant on technologies and become less satisfied in traditional presentations ${ }^{24}$. In addition, media and method that are less varied make students not interested in learning Arabic ${ }^{25}$. It indicates that different instructional strategies and media are needed ${ }^{26}$. According to the gap presented above, improving the process and student learning outcome in Tarkib by using the Flipped Classroom Strategy assisted with EPUB media is needed. Hopefully, choosing EPUB media can facilitate students learning language independently ${ }^{27}$ using interactive media and content ${ }^{28,29}$, and solving the learning difficulties ${ }^{30,31}$.

This study aims to implement the flipped classroom strategy with epub digital material to enhance students learning outcomes on tarkib. The results of this study contributes to enhancing the learning quality of Arabic in non-language classes. Since the students are not interested in learning Arabic, the implementation of Flipped Classroom Strategy with Epub Digital Material can be a solution.

${ }^{24}$ Babak Sohrabi dan Hamideh Iraj, "Implementing Flipped Classroom Using Digital Media: A Comparison of Two Demographically Different Groups Perceptions," Computers in Human Behavior 60 (1 Juli 2016): 514-24, https://doi.org/10.1016/j.chb.2016.02.056.

${ }^{25}$ Asep Muhammad Saepul Islam, "Faktor Demotivasi Pembelajaran Bahasa Arab Dalam Perspektif Siswa Madrasah," Arabiyat : Jurnal Pendidikan Bahasa Arab dan Kebahasaaraban 2, no. 1 (1 Juli 2015): 1-16, https://doi.org/10.15408/a.v2i1.1511.

${ }^{26}$ Marc Prensky, "Digital Natives, Digital Immigrants Part 2: Do They Really Think Differently?," On The Horizon 9, no. 6 (2001): 4.

${ }^{27}$ Faishal Aji Zulmi dan Isa Akhlis, "Pengembangan LKPD Berekstensi EPUB Berbasis Discovery Learning Untuk Mengembangkan Keterampilan Berpikir Kritis Peserta Didik," UPEJ Unnes Physics Education Journal 9, no. 2 (18 Oktober 2020): 209-16, https://doi.org/10.15294/upej.v9i2.41373.

${ }^{28}$ Valentina Bartalesi dan Barbara Leporini, "An enriched ePub eBook for screen reader users" (International Conference on Universal Access in Human-Computer Interaction, Springer, 2015), 375-86.

${ }^{29}$ Hao Shi, "Developing E-Learning Materials for Software Development Course," International Journal of Managing Information Technology 2, no. 2 (31 Mei 2010): 15-21, https://doi.org/10.5121/ijmit.2010.2202.

${ }^{30}$ M. Islamy dkk., "Developing Social Studies Teaching Materials Based on Multimedia EPUB for The Effectiveness on Learning Outcomes," vol. 1 The 1st International Conference on Islam, Science and Technology (ICONIST), Slovakia: European Alliance for Innovation (EAI) (2020), np, https://doi.org/10.4108/eai.2-10-2018.2295460.

31 Haning Hasbiyati dan K Laila, "Penerapan Media E-Book Bereksistensi EPUB untuk Meningkatkan Minat dan Hasil Belajar Siswa SMP pada Mata Pelajaran IPA," Jurnal Pena Sains 4, no. 1 (2017): 16-21, https://doi.org/10.21107/jps.v4i1.2775. 


\section{Method}

This research is quantitative approach which used quasi experiment non equivalent control group design ${ }^{32}$. This research design is used to see the equality in efforts $^{33}$ in efforts to enhance the understanding of student on tarkib. This research conducted in MAN 4 Hulu Sungai Tengah Barabai, Kalimantan Selatan. The object of this research are two classes, X IPA 2 contains 26 students and X IPA 1 contains 29 students. X IPA 1 was chosen as an experimental group, and X IPA 2 was chosen as control group. The classes were determined based on the equality of identity and learning achievement on tarkib which still on below the passing grade. The steps of this research are pretest, treatment, and posttest. Data were analyzed using the normality test with Kolmogorov-Smirnov, homogeneity test using Lavene, and Hypothesis test. The comparative results of the analysis both pretest and posttest on the control and the experimental group used as a fixed point to test the hypothesis of research.

The pretest was carried out before testing the hypothesis. They were a normality test and homogeneity test. The results showed that the distribution of data was normal and significant difference between control and experimental group was not found out. Then, an independent t-test was used to compare the scores between the two groups. The significance level of 0.05 was used as a criteria to determine the null hypothesis, eiter rejecting or accepting. In the field of educational research it is an acceptable level. If the results of the independent t-test showed that the significance level is lower than the criteria level, it can be understood that the control and the experimental group are different significantly. So, the null hypothesis is not accepted. Otherwise, if the results of the independent t-test showed that the significance level is higher than the criteria level, it can be understood that the control and the experimental group are not different significantly. So, the null hypothesis is accepted.

This learning strategy is carried out in this study is a Flipped Classroom with Epub Digital Book. First, the teacher distributed the materials supported by instructional videos before the class, so students learn the material first. It offers students an opportunity to monitor their learning and evaluates their understanding of the lesson. In this part, students acquire the first and the second level in cognitive taxonomies, namely

${ }^{32}$ John W. Cresswell dan J. David Cresswell, Research Design: Qualitative, Quantitative, and Mixed Methods Approaches (Sage Publication, 2017), 49.

${ }^{33}$ Kim D Reynolds dan Stephen G West, "A multiplist strategy for strengthening nonequivalent control group designs," Evaluation Review 11, no. 6 (1987): 691-714.

5 | Jurnal Al Bayan: Jurnal Jurusan Pendidikan Bahasa Arab, 13 (1): 1-15 (2021) 
remembering and understanding. Next, the teacher raised questions to students about tarkib, and ask them to carry out group discussion to solve the problems. In this part, students acquire the third and the fourth level in cognitive taxonomies, which are applying and analyzing. After that, at the end of the class session, students asked to investigate the grammatical rules in some texts and practice making simple sentences using learned rules. In this part, students acquired the fifth and the sixth level in cognitive taxonomies.

The table below explains the steps of the implementation the flipped classroom strategy:

Tabel 1. Steps of Flipped Classroom Strategy

\begin{tabular}{|c|c|}
\hline Steps & Details \\
\hline Preparation & Designing the lesson plan \\
\hline \multirow[t]{7}{*}{$\begin{array}{l}\text { Prior to the } \\
\text { class }\end{array}$} & $\begin{array}{l}\text { Epub production that consist of: } \\
\text { a. Concept mapping } \\
\text { b. Troubleshooting tasks } \\
\text { c. Explanation of material } \\
\text { d. Task of discussion }\end{array}$ \\
\hline & $\begin{array}{l}\text { The layout is presented in attractive and wonderfull color and design. Also, a learning } \\
\text { support video is made. (Material and video screenshot attached) }\end{array}$ \\
\hline & The teacher sends materials and videos through Whatsapp groups \\
\hline & The teacher and students discuss material online \\
\hline & The teacher prepares the pretest instrument \\
\hline & The teacher asks the instrument validation expert \\
\hline & The teacher does the pretest in the experimental and control groups \\
\hline Implementation & The teacher asks students to divide groups \\
\hline \multirow[t]{8}{*}{ During Class } & The teacher starts learning by reading hiwar which is followed by students \\
\hline & Students practice hiwar in front of the class with fashih (C3) \\
\hline & Students analyze the sentence-forming words found in hiwar (C4) \\
\hline & Students identify the type of khobar found in hiwar (C4) \\
\hline & Students discuss the conditions of khobar mufrad \\
\hline & Students analyze the characteristics of the mufrad khabar in the sentence (C4) \\
\hline & Students investigate the incorrect rules in the text (C5) \\
\hline & Students make the number of ismiyah with khobar mufrad according to the rules (C6) \\
\hline Evaluation & Students encourage to express their perception and suggestion of learning activities \\
\hline \multirow[t]{2}{*}{ After Class } & $\begin{array}{l}\text { The teacher asks students to re-evaluate the material and make sentences according to } \\
\text { the rules }\end{array}$ \\
\hline & The teacher does the pretest \\
\hline
\end{tabular}

\section{Result and Discussion}

\section{Normality Test}

The result of the normality test showed that the significance value of Asymp.Sig (2-tailed) was 0.002 . It was higher that 0.05 , thus it can be said that data of pretest and posttest of the experimental group distributed normally. 


\section{Homogeneity Test}

The result of the homogeneity test showed that the Sig. Based on the mean for the posttest variables of the experimental and control groups was $0.005<0.05$, thus it can be said that the data variance was not homogeneous.

\section{Hypothesis Test (significance)}

Since the data distributed normally and not homogeneous, the hypothesis test was carried out using the independent t-test formula.

Table 2. The Result of Independent Samples Test

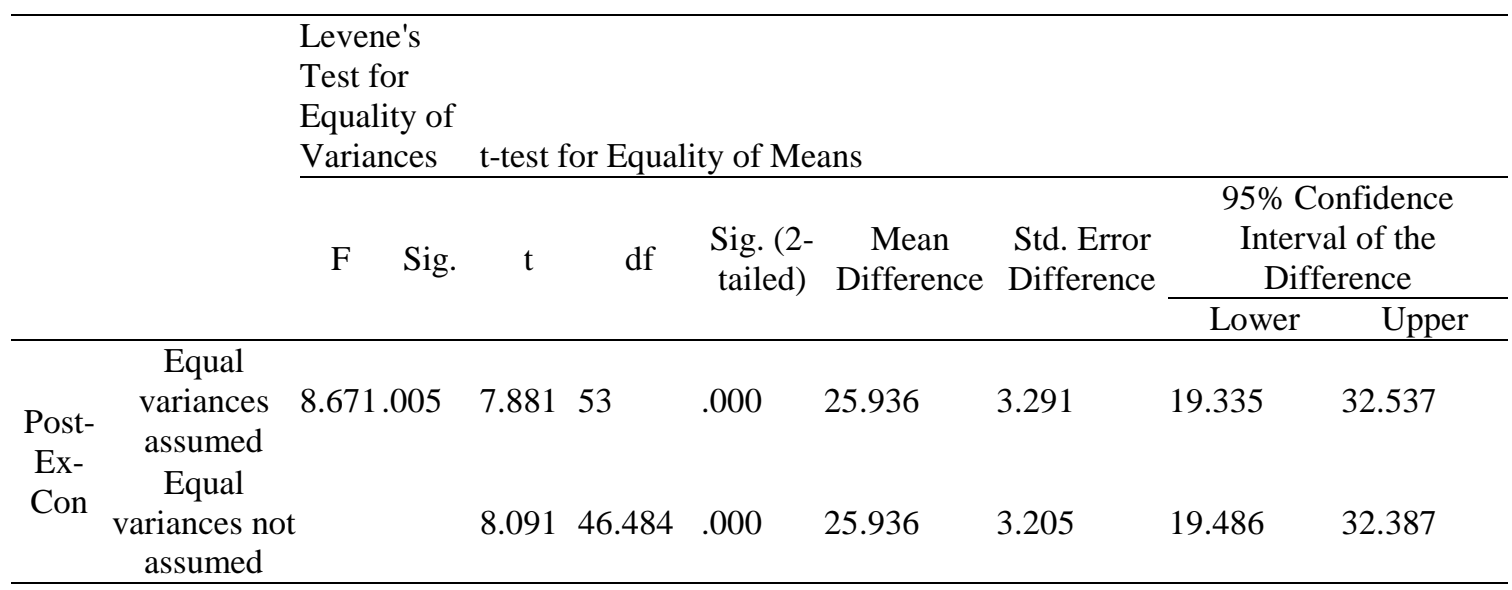

From table 2 above, the significance value of $0.000<0.05$ means that there is a significant difference in learning outcomes between the experimental class using the flipped classroom method with the epub media compared to the control class which only uses the qawaid wa tarjamah method. Students learning outcomes in the Flipped Classroom are higher than the learning outcomes of students in the traditional class. It confirmed that flipped classroom is more effective to increase learning outcomes ${ }^{34}$.

${ }^{34}$ Ridha, Setyosari, dan Kuswandi, "Pengaruh Flipped Mastery Classroom Terhadap Perolehan Hasil Belajar Kognitif Mahasiswa"(Op.cit); Mu'alim Wijaya dan Nafilatul Hasanah, "Implementasi Pembelajaran Kitab Kuning Melalui Model Pembelajaran Flipped Classroom," Murobbi: Jurnal Ilmu Pendidikan 3, no. 1 (2019): 1-20; Torstein Låg dan Rannveig Grom Saele, "Does the Flipped Classroom Improve Student Learning and Satisfaction? A Systematic Review and Meta-Analysis," AERA Open 5, no. 3 (2019): 6, https://doi.org/10.1177/2332858419870489; Namhee Kang, "The Comparison between Regular and Flipped Classrooms for EFL Korean Adult Learners," Multimedia Assisted Language Learning 18, no. 3 (2015): 61; Zeynep Turan dan Birgul Akdag-cimen, "Flipped classroom in English language teaching: a systematic review Flipped classroom in English language teaching: a systematic review," Computer Assisted Language Learning 0, no. $0 \quad$ (2019): 12, https://doi.org/10.1080/09588221.2019.1584117; Aburezeq, "The Impact of Flipped Classroom on Developing Arabic Speaking Skills.” 
The implementation of Flipped Classroom Strategy allows for more preparation, more time to practice problem-solving, and meaningful learning activities ${ }^{35}$. It can handle a wide variety of active learning elements like student engagement, whether in teams or $\operatorname{not}^{36}$. It allowed students to study learning material easier but more comprehensive ${ }^{37}$, and more engaged in the learning process ${ }^{38}$. Mas'ud \& Surjono ${ }^{39}$ found out that the flipped classroom increases student participation and gives a positive impact on students performance and learning achievement. Meanwhile, when learning takes place traditionally, students only listen to the teacher's explanation about grammatical rules and translate the Arabic text into Indonesian. It is called al Qawaid wa al Tarjamah. Then, students should memorize the explanation of the teachers and retrieve it on an $\operatorname{exam}^{40}$. It also assumes students as a passive learner. Students used to wait for the teacher's explanation without any excitement to learn and curiousity.

We argued that the reason behind students' achievement in traditional class is their engagement in the learning process. Moreover, it did not promote student-centered learning. The study conducted by Jensen, Kummer, \& Godoy ${ }^{41}$ found out that flipped classroom is not better than another strategy when both blend an active-learning, and constructivist approach. Students performances are either low level or high level in both class are equal.

The implementation of the flipped classroom promotes student-centered learning. The teacher is only as a facilitator, motivator, and student partner in learning ${ }^{42}$. Students

35 Abdulrahman M Al-zahrani, "From passive to active: The impact of the flipped classroom through social learning platforms on higher education students' creative thinking," British Journal of Educational Technology 46, no. 6 (2015), https://doi.org/10.1111/bjet.12353.

${ }^{36}$ Njål Foldnes, "The flipped classroom and cooperative learning: Evidence from a randomised experiment," Active Learning In Higher Education 17, no. 1 (2016): 48, https://doi.org/10.1177/1469787415616726. (Op.Cit)

${ }^{37}$ Bergmann dan Sams, Flipped Your Classroom Reach Every Student Everyday Class Every Day.

${ }^{38}$ Huzaima Mas'ud dan Herman Dwi Surjono, “The Implementation of Flipped Classroom Learning Model Using Moodle To Increase Students 'Higher Order Thinking Skills," Journal of Educational Science and Technology 4, no. 3 (2018): 187-94.

${ }^{39}$ Mas'ud dan Surjono.

40 Alison King, "From Sage on The Stage to Guide on The Side," College Teaching 41, no. 1 (2013): 30 .

${ }^{41}$ Jamie L. Jensen, Tyler A. Kummer, dan Patricia D. d. M. Godoy, "Improvements from a Flipped Classroom May Simply Be the Fruits of Active Learning," CBE-Life Sciences Education 14, no. 1 (2 Maret 2015): 1-12, https://doi.org/10.1187/cbe.14-08-0129.

42 Ahmet Basal, "The Implementation of a Flipped Classroom in Foreign Language Teaching," Turkish Online Journal of Distance Education 16, no. 4 (Oktober 2015): 28-37. 
should be more active independently to learn in a way that suits themselves ${ }^{43}$. Therefore, the flipped classroom was difficult to implement. It makes students confused because there was a drastic change in the way they learned. The students resisted the flipped classroom in the beginning ${ }^{44}$. Before its implementation, teachers should encourage students to be active in group discussions and dare to express their opinion and confirm their understanding. Moreover, teachers should design materials into two categories. The first one is for outside class activities, and the next one is for class session activities. Teachers deliver material to students before class begins. Then, students are responsible to remember and understand the material ${ }^{45}$.

In this study, the implementation of the Flipped Classroom has challenges because some students have never learned Arabic at all, and some have ever learned, but forgotten most of the material because they do not like Arabic. The experience of students in learning is the essential factor in their learning motivation. However, Hung ${ }^{46}$ confirmed that students become more active if teacher give the material prior to the class session to students. It gives students more opportunities to learn before class meetings, a chance to review the lesson, a chance to study the lower-order thinking skills in their pace, and was able to write their notes and comments regarding the lesson ${ }^{47}$. Students that well prepared before class generally enjoyed flipped-classroom activities and more chances to engage in in-class activities ${ }^{48}$. So, the teachers need to design the materials carefully before delivering them to students.

In this study, the materials contain the indicators of achievement that allow students to know their learning purpose. It also supported with concept maps and problem-solving in daily conversation. To get a detailed understanding, the explanation of the materials arranged in concise charts and completed with examples. Moreover,

43 Evseeva dan Solozhenko, "Use of Flipped Classroom Technology in Language Learning"; Alsowat, "An EFL Flipped Classroom Teaching Model: Effects on English Language Higher-order Thinking Skills, Student Engagement and Satisfaction," 117.

${ }_{44}$ Jessica M Fautch, "Research and Practice The flipped classroom for teaching organic chemistry in small classes: is it effective?," Chemistry Education Research and Practice 16 (2015): 182, https://doi.org/10.1039/C4RP00230J.

45 Sarah J. Delozier dan Matthew G Rhodes, "Flipped Classrooms : a Review of Key Ideas and Recommendations for Practice," Educ Psychol Rev, (2016): 8, https://doi.org/10.1007/s10648-015-9356-9.

46 "Flipping the classroom for English language learners to foster active learning," Computer Assisted Language Learning 28, no. 1 (2015): 81-96, https://doi.org/10.1080/09588221.2014.967701.

${ }^{47}$ Marin Moravec dkk., "Learn before Lecture : A Strategy That Improves Learning Outcomes in a Large Introductory Biology Class,” CBE-Life Sciences Education 9 (2010): 473-81, https://doi.org/10.1187/cbe.10. 
some questions for group work are included in the materials, and short explanatory videos from the teachers for supporting the material are available. Students preferred videos which are not didactic ${ }^{49}$. The short videos contain interactive content and brief explanation. It does not only focus on explanation, but also its examples, so it can facilitate the development of cognitive domain of students.

Students are well prepared before class generally and they enjoyed flippedclassroom activities and more opportunities to engage the class activities ${ }^{50}$. It leads to an increase in motivation to learn ${ }^{51}$. However, the teacher should be careful about their behavioral engagement in learning activities at home ${ }^{52}$. Student's self-directed learning skills has a significant role in their motivation and satisfaction in classroom activities ${ }^{53}$.

At the end of the class session, the teacher reordering the sentence patterns that students have understood and the sentences patterns they have not understood yet. Then the teacher ask the students to evaluate their understanding. After that, to enrich students understanding of the material, the discussion held by teacher continue outside class through Whatsapp Group. In order to maintain students focus, the materials was designed in specific topic. The last, students are asked to make few sentences based on the material they have mastered. This learning strategy is really supportive for learning sustainable.

This study is in accordance with previous researches which showed that the implementation of flipped classroom can increase student participation in learning and give a positive impact on student performance and learning achievement. Eventhough Flipped Classroom is quite difficult to be implemented, students' outcomes and their

${ }^{48}$ N. Kang, "The Comparison between Regular and Flipped Classrooms for EFL Korean Adult Learners" 18, no. 3 (2015): 41-72, https://doi.org/10.15702/MALL.2015.18.3.41.

49 Babak Sohrabi dan Hamideh Iraj, "Implementing flipped classroom using digital media : A comparison of two demographically different groups perceptions," Computers in Human Behavior 60 (2016): 514-24, https://doi.org/10.1016/j.chb.2016.02.056.

${ }^{50} \mathrm{M}$ Kang dan T Imt, "Factors of learner - instructor interaction which predict perceived learning outcomes in online learning environment," Journal of Computer Assisted Learning 29 (2013): 61, https://doi.org/10.1111/jcal.12005.

${ }^{51}$ Erhan Şengel, "To FLIP or Not to FLIP: Comparative Case Study in Higher Education in Turkey," Computers in Human Behavior 64 (1 November 2016): 547-55, https://doi.org/10.1016/j.chb.2016.07.034.

52 Jihyun Lee, Taejung Park, dan Robert Otto Davis, "What Affects Learner Engagement in Flipped Learning And What predicts its outcomes ?," British Journal of Educational Technology 0, no. 0 (2018): 11, https://doi.org/10.1111/bjet.12717.

${ }_{53}$ Ramazan Yilmaz, "Exploring the role of e-learning readiness on student satisfaction and motivation in flipped classroom," Computers in Human Behavior 70 (2017): 257, https://doi.org/10.1016/j.chb.2016.12.085. 
participation in the class activities improved $^{54}$. Moreover, students have more positive attitudes towards the course activities such as participating more active and attentive, interacting with other students in class and having a good relationship with other students to be successful in the class 55 .

\section{Conclusion}

The implementation of flipped classroom strategy with epub digital material on MAN 4 HST was found out to be effective to enhance students understanding on tarkib. The result of the independent sample t-test showed that Sig. Value (2-tailed) in the column of equal variances not assumed is $0,000<0.05$. It means students learning outcome in the experimental class is higher than learning outcomes in the control class. Students also have more opportunities to construct their knowledge and practice their skills. This research has some limitations, such as preliminary research about Arabic skills of students was not conducted, and learning time allocation was limited. The Flipped Classroom give students the opportunity and responsibility to remember and understand the material before teaching and learning activity in the class. This point seems to be overwhelmed for students. They feel confused and their skill to search for learning resources independently is low. Moreover, in the teaching and learning process by using the flipped classroom strategy, their learning motivation was also unknown. For the next research, it is expected to have the observation about the use of the flipped classroom strategy in teaching and learning for other skills in Arabic and to explore more benefits in implementing a flipped classroom with epub materials.

\section{Acknowledgment}

Thanks to the Madrasah Aliyah Negeri 4 Hulu Sungai Tengah and all of the colleagues who have helped in the accomplishment of this research.

${ }^{54}$ Zeynep Turan dan Birgul Akdag-Cimen, "Flipped classroom in English language teaching: a systematic review," Computer Assisted Language Learning 33, no. 5-6 (3 Juli 2020): 590-606, https://doi.org/10.1080/09588221.2019.1584117. 


\section{References}

Aburezeq, Ibtehal Mahmoud. "The Impact of Flipped Classroom on Developing Arabic Speaking Skills." The Asia-Pacific Education Researcher, 2019. https://doi.org/10.1007/s40299-019-00483-z.

Albahuoth, Haifa. "Effectiveness of flipped classroom in developing 11th graders' grammatical competences in Arabic." Interactive Learning Environments, 2020, 117.

Alsowat, Hamad. "An EFL Flipped Classroom Teaching Model: Effects on English Language Higher-order Thinking Skills , Student Engagement and Satisfaction." Journal of Education And Practice 7, no. 9 (2016): 108-21.

Alwaely, S. Methods of teaching literature, rhetoric, and expression: Between theory and application. Amman: Dar Alshurooq, 2004.

Al-Zahrani, Abdulrahman M. "From Passive to Active: The Impact of the Flipped Classroom through Social Learning Platforms on Higher Education Students' Creative Thinking." British Journal of Educational Technology 46, no. 6 (2015): 1133-48. https://doi.org/10.1111/bjet.12353.

Azizi, Rozika, Anwar Sa'dullah, dan Mohammad Afifulloh. "Strategi Guru Mengatasi Kesulitan Belajar Siswa Pada Mata Pelajaran Bahasa Arab Di Madrasah Tsanawiyah Yaspuri Kota Malang.” Vicratina: Jurnal Pendidikan Islam 4, no. 6 (13 Juli 2019): 102-12.

Bartalesi, Valentina, dan Barbara Leporini. "An enriched ePub eBook for screen reader users," 375-86. Springer, 2015.

Basal, Ahmet. "The Implementation of a Flipped Classroom in Foreign Language Teaching." Turkish Online Journal of Distance Education 16, no. 4 (Oktober 2015): 28-37.

Bergmann, Jonathan, dan Aaron Sams. Flip Your Classroom: Reach Every Student in Every Class Every Day. Washington, D.C, America: International Society for Technology in Education, 2012.

Cresswell, John W., dan J. David Cresswell. Research Design: Qualitative, Quantitative, and Mixed Methods Approaches. Sage Publication, 2017.

Delozier, Sarah J., dan Matthew G Rhodes. "Flipped Classrooms : a Review of Key Ideas and Recommendations for Practice." Educ Psychol Rev, 2016. https://doi.org/10.1007/s10648-015-9356-9.

${ }^{55}$ Brenton Mcnally dkk., "Flipped classroom experiences : student preferences and flip strategy in a higher education context," Higher Education 73, no. 2 (2017): 281-98, https://doi.org/10.1007/s10734016-0014-z. 
Evseeva, Arina, dan Anton Solozhenko. "Use of Flipped Classroom Technology in Language Learning." Procedia - Social and Behavioral Sciences 206, no. November (2015): 205-9. https://doi.org/10.1016/j.sbspro.2015.10.006.

Fahrurrozi, Aziz. "Pembelajaran Bahasa Arab: Problematika dan Solusinya." Arabiyat: Jurnal Pendidikan Bahasa Arab dan Kebahasaaraban 1, no. 2 (2014).

Fautch, Jessica M. "Research and Practice The flipped classroom for teaching organic chemistry in small classes : is it effective ?" Chemistry Education Research and Practice 16 (2015): 179-86. https://doi.org/10.1039/C4RP00230J.

Foldnes, Njål. "The flipped classroom and cooperative learning: Evidence from a randomised experiment." Active Learning In Higher Education 17, no. 1 (2016): 39-49. https://doi.org/10.1177/1469787415616726.

Fuadi, Faturahman. "Analisis Kesulitan Belajar Bahasa Arab:" Al-Lisan: Jurnal Bahasa (e-Journal) 4, no. 2 (1 Agustus 2019): 161-69.

Green, Lucy Santos, Jennifer R Banas, dan Ross A Perkins, ed. The Flipped College Classroom: Conceptualized and Re-Conceptualized. Cham: SpringerInternational Publishing Switzerland, 2017.

Hasbiyati, Haning, dan K Laila. "Penerapan Media E-Book Bereksistensi EPUB untuk Meningkatkan Minat dan Hasil Belajar Siswa SMP pada Mata Pelajaran IPA." Jurnal Pena Sains 4, no. 1 (2017): 16-21. https://doi.org/10.21107/jps.v4i1.2775.

Hung, Hsiu-ting. "Flipping the classroom for English language learners to foster active learning." Computer Assisted Language Learning 28, no. 1 (2015): 81-96. https://doi.org/10.1080/09588221.2014.967701.

Islam, Asep Muhammad Saepul. "Faktor Demotivasi Pembelajaran Bahasa Arab Dalam Perspektif Siswa Madrasah.” Arabiyat: Jurnal Pendidikan Bahasa Arab dan Kebahasaaraban 2, no. 1 (1 Juli 2015): 1-16. https://doi.org/10.15408/a.v2i1.1511.

Islamy, M., Muhammad Amrullah, Agus Riwanda, Nuril Mufidah, Luthfiya Pusposari, dan Abdul Fattah. "Developing Social Studies Teaching Materials Based on Multimedia EPUB for The Effectiveness on Learning Outcomes," 1:np. Slovakia: European Alliance for Innovation (EAI), 2020. https://doi.org/10.4108/eai.2-102018.2295460.

Jensen, Jamie L., Tyler A. Kummer, dan Patricia D. d. M. Godoy. "Improvements from a Flipped Classroom May Simply Be the Fruits of Active Learning." CBE-Life Sciences Education 14, no. 1 (2 Maret 2015): 1-12. https://doi.org/10.1187/cbe.1408-0129.

Kang, M, dan T Imt. "Factors of learner - instructor interaction which predict perceived learning outcomes in online learning environment." Journal of Computer Assisted Learning 29 (2013): 292-301. https://doi.org/10.1111/jcal.12005. 
Kang, Namhee. "The Comparison between Regular and Flipped Classrooms for EFL Korean Adult Learners." Multimedia Assisted Language Learning 18, no. 3 (2015): 41-72.

Kim, Jeong-eun, dan Hyunjin Park. "Exploring Flipped Classroom Effects on Second Language Learners ' Cognitive Processing." Foreign Language Annals 50, no. 2 (2017): 260-84. https://doi.org/10.1111/flan.12260.

King, Alison. "From Sage on The Stage to Guide on The Side." College Teaching 41, no. 1 (2013): 30-35.

Låg, Torstein, dan Rannveig Grom Saele. "Does the Flipped Classroom Improve Student Learning and Satisfaction? A Systematic Review and Meta-Analysis." AERA Open 5, no. 3 (2019): 1-17. https://doi.org/10.1177/2332858419870489.

Lai, Chiu-Lin, dan Gwo-Jen Hwang. "A Self-Regulated Flipped Classroom Approach to Improving Students' Learning Performance in a Mathematics Course.” Computers \& Education $\quad 100 \quad(1 \quad$ September 2016): 126-40. https://doi.org/10.1016/j.compedu.2016.05.006.

Lee, Jihyun, Taejung Park, dan Robert Otto Davis. "What Affects Learner Engagement in Flipped Learning And What predicts its outcomes?" British Journal of Educational Technology 0, no. 0 (2018): 1-18. https://doi.org/10.1111/bjet.12717.

Li, Shuangjiang, dan Jitpanat Suwanthep. "Integration of flipped classroom model for EFL speaking." International Journal of Learning and Teaching 3, no. 2 (2017): $118-23$.

Mas'ud, Huzaima, dan Herman Dwi Surjono. "The Implementation of Flipped Classroom Learning Model Using Moodle To Increase Students ' Higher Order Thinking Skills." Journal of Educational Science and Technology 4, no. 3 (2018): 187-94.

Mcnally, Brenton, Janine Chipperfield, Pat Dorsett, Letitia Del, Fabbro Valda, Frommolt Sandra, Gregory Reddan, Anne Roiko, dan Andrea Rung. "Flipped classroom experiences : student preferences and flip strategy in a higher education context." Higher Education 73, no. 2 (2017): 281-98. https://doi.org/10.1007/s10734-0160014-z.

Moravec, Marin, Adrienne Williams, Nancy Aguilar-roca, dan Diane K O Dowd. "Learn before Lecture: A Strategy That Improves Learning Outcomes in a Large Introductory Biology Class.” CBE—Life Sciences Education 9 (2010): 473-81. https://doi.org/10.1187/cbe.10.

Najah, Zughrofiyatun, dan Azzah Saniyyah Maulana. "Mahârah Al-Kitâbah Learning Through Mind Mapping Strategies.” Jurnal Al Bayan: Jurnal Jurusan Pendidikan Bahasa Arab 11, no. 2 (9 Desember 2019): 340-55. https://doi.org/10.24042/albayan.v11i2.5038. 
Nunan, David. Designing tasks for the communicative classroom. Cambridge: Cambridge University Press Cambridge, 2001.

Prensky, Marc. "Digital Natives, Digital Immigrants Part 2: Do They Really Think Differently?" On The hORIZON 9, no. 6 (2001): 1-9.

Reynolds, Kim D, dan Stephen G West. "A multiplist strategy for strengthening nonequivalent control group designs." Evaluation Review 11, no. 6 (1987): 691714.

Ridha, Muhammad, Punaji Setyosari, dan Dedi Kuswandi. "Pengaruh Flipped Mastery Classrom Terhadap Perolehan Hasil Belajar Kognitif Mahasiswa." Jurnal Pendidikan: Teori, Penelitian, dan Pengembangan 1, no. 4 (1 April 2016): 655-61. https://doi.org/10.17977/jp.v1i4.6211.

Sadeghi Beniss, Aram Reza, dan Vahid Edalati Bazzaz. "The Impact of Pushed Output on Accuracy and Fluency of Iranian EFL Learners' Speaking." Iranian Journal of Language Teaching Research 2, no. 2 (Juli 2014). https://doi.org/10.30466/ijltr.2014.20413.

Şengel, Erhan. "To FLIP or Not to FLIP: Comparative Case Study in Higher Education in Turkey." Computers in Human Behavior 64 (1 November 2016): 547-55. https://doi.org/10.1016/j.chb.2016.07.034.

Shi, Hao. "Developing E-Learning Materials for Software Development Course." International Journal of Managing Information Technology 2, no. 2 (31 Mei 2010): 15-21. https://doi.org/10.5121/ijmit.2010.2202.

Sohrabi, Babak, dan Hamideh Iraj. "Implementing flipped classroom using digital media: A comparison of two demographically different groups perceptions." Computers in Human Behavior 60 (2016): $514-24$. https://doi.org/10.1016/j.chb.2016.02.056.

Turan, Zeynep, dan Birgul Akdag-Cimen. "Flipped classroom in English language teaching: a systematic review." Computer Assisted Language Learning 33, no. 5-6 (3 Juli 2020): 590-606. https://doi.org/10.1080/09588221.2019.1584117.

Wijaya, Mu'alim, dan Nafilatul Hasanah. "Implementasi Pembelajaran Kitab Kuning Melalui Model Pembelajaran Flipped Classroom." Murobbi: Jurnal Ilmu Pendidikan 3, no. 1 (2019): 1-20.

Yilmaz, Ramazan. "Exploring the role of e-learning readiness on student satisfaction and motivation in flipped classroom." Computers in Human Behavior 70 (2017): 25160. https://doi.org/10.1016/j.chb.2016.12.085.

Zulmi, Faishal Aji, dan Isa Akhlis. "Pengembangan LKPD Berekstensi EPUB Berbasis Discovery Learning Untuk Mengembangkan Keterampilan Berpikir Kritis Peserta Didik." UPEJ Unnes Physics Education Journal 9, no. 2 (18 Oktober 2020): 20916. https://doi.org/10.15294/upej.v9i2.41373. 